\title{
Risk Management Berdasarkan Framework Pada Aktifitas Perusahaan Jasa Konsultasi Dengan ISO 31000:2018
}

\author{
Mohammad Arief Nur Wahyudien $1^{1)}$, Elisa Kusrini $2^{2)}$ \\ Jurusan Magister Teknik Industri, Fakultas Teknologi Industri, Universitas Islam Indonesia Jalan Kaliurang \\ km 14,5 Sleman, Yogyakarta 55501 \\ E-Mail :Mohammadarief2295@gmail.com ${ }^{l)}$,elisakusrini@uii.ac.id ${ }^{2)}$
}

\begin{abstract}
ABSTRAK
Tujuan penelitian ini untuk mengidentifikasi, menganalisa dan memitigasi risiko berdasarkan KPI perusahaan untuk seluruh aktivitas perusahaan sehingga meningkatkan kinerja perusahaan dalam memberikan pelayanan pada klien kedepannya. Pada perusahaan jasa konsultasi di setiap aktifitas perusaaan akan rentang terhadap risiko sehingga dapat merugikan perusahaan dan hilangnya kepercayaan klien dalam menggunakan jasa konsultasi ini untuk selanjutnya. Aktivitas perusahaan akan berjalan dengan baik jika manajemen risiko dilakukan dengan sebuah kerangka kerja untuk memudahkan dalam mengelola risiko. Metode penelitian dengan pendekatan ISO 31000 digunakan untuk mengidentifikasi, menganalisa dan memitigasi risiko. Ada 5 variable yang di teliti adalah strategi dan governance, proses bisnis, struktur, teknologi dan people. Hasil dari penelitian ini ada 40 jenis risiko yang teridentifikasi dari kuisioner yang dibagikan ke pihak perusahaan. Hasil dari mitigasi risiko yang dilakukan di perusahaan jasa konsultasi pada kelima variabel yakni perusahaan harus melakukan evaluasi secara rutin dari setiap devisi dan mitra kerja, memperjelas tugas dan tanggung jawab untuk setiap devisi dan karyawan, memberikan pelatihan- pelatihan kepada karyawan dalam masing masing bidang untuk meningkatkan kualitas pelayanan dan kinerja perusahaan.
\end{abstract}

Kata kunci: Framework, ISO 31000:2018, Manajemen Resiko, Perusahaan Jasa

\section{Risk Management Based on Framework of Activities of Consulting Services Companies With ISO 31000: 2018}

\begin{abstract}
The purpose of this study is to identify, analyze, and mitigate risks based on the company's KPI for all company activities to improve the company's performance in providing services to clients in the future. In a consulting service company, in every activity, the company will be exposed to a risk so that it can harm the company and the loss of client confidence in using this consulting service in the future. Company activities will run well if risk management is carried out with a framework to facilitate risk management. Research methods with the ISO 31000 approach are used to identify, analyze, and mitigate risks. There are 5 variables studied are strategy and governance, business processes, structure, technology, and people. The results of this study were 40 types of risks identified from the questionnaires distributed to the company. The results of risk mitigation carried out in consulting service companies on the five variables, namely the company must regularly evaluate each division and work partner, clarify the duties and responsibilities for each division and employee, provide training to employees in each field to improve service quality and company performance.
\end{abstract}

Keywords: Framework, ISO 31000: 2018, Risk Management, Service Companies

\section{Pendahuluan}

Pelayanan didefinisikan sebagai kegiatan ekonomi yang menghasilkan waktu, tempat, bentuk, dan penggunaan psikologis (Haksever, Render, Russell, \& Murdick, 2000). Pelayanan berfokus pada penawaran kepada pelanggan, sehingga pelayanan adalah segalanya pada tingkat abstrak dan dapat dioperasionalkan dan diinterpretasikan dengan cara yang berbeda. Pelayanan pada tingkat empiris mencakup berbagai 
penawaran, organisasi, dan pelanggan (Edvardsson, Gustafsson, \& Ross, 2005).

Di perusahaan jasa, pelanggan adalah input. Pelayanan yang diberikan tidak dapat dilakukan tanpa kehadiran pelanggan dan informasi dari pelanggan diperlukan sebagai masukan untuk perusahaan jasa. Industri jasa juga dapat diukur sama dengan industri manufaktur, yaitu produktivitas, kualitas layanan, dan efisiensi (Johnston, 2005).

Dalam menjalankan bisnis perusahaan jasa tidak terlepas dari risiko yang dihadapi. Risiko adalah ketidakpastian yang berdampak pada pencapaian tujuan (Sutanto, 2012). Risiko perlu dikelola dengan baik untuk melihat kemungkinan kejadian sehingga perusahaan dapat menyiapkan rencana mitigasi dan tindakannya.

Dalam melakukan analisis risiko perlu ada framework yang jelas untuk memfasilitasi perusahaan dalam mengelola risiko (Yoga \& Punjawa, 2009).

Framework dapat menghubungkan manajemen risiko dengan kegiatan manajemen lainnya di dalam sebuah organisasi. Ini sangat penting untuk keberhasilan manajemen risiko, dimana framework memberikan dasar dan aturan yang digunakan di setiap organisasi di semua tingkatan (Sousa, De-Almeida, \& Dias, 2012).

Manajemen risiko yang baik dan efektif untuk setiap aktivitas internal dan eksternal perusahaan harus dapat melindungi nilai dan menambah nilai perusahaan (Candra, Sari, Iskandar, \& Yanto, 2019).

Dalam melaksanakan proses manajemen risiko terdiri dari beberapa tahapan, yaitu penentuan konteks dan kriteria, penilaian risiko terdiri dari identifikasi risiko, analisis risiko, dan evaluasi risiko, dan akhirnya penanganan risiko (The British Standar Institution, 2018).

Identifikasi risiko dilakukan untuk menemukan, mengenali, dan menggambarkan risiko-risiko ini. Analisis risiko dilakukan untuk memahami sifat, karakteristik, dan tingkat risiko. Evaluasi risiko dilakukan untuk mendukung penentuan tindakan dan keputusan yang akan diambil (De-Oliveira, Marins, Rocha, \& Salomon, 2017).

Dalam penelitian ini, manajemen risiko didasarkan pada kerangka yang diusulkan oleh PwC. Kerangka yang diusulkan oleh PwC digunakan dalam mengukur masalah yang terjadi dalam proses aktivitas SRM di perusahaan jasa. Struktur kerangka kerja PwC terdiri dari strategi dan pemerintah, proses, struktur, karyawan, teknologi, manajemen kinerja, dan manajemen risiko (Remko, 2013).

Kerangka kerja PwC berfungsi sebagai referensi dalam mengidentifikasi semua kegiatan perusahaan jasa baik secara internal maupun eksternal sehingga dalam mengidentifikasi risiko akan lebih terstruktur dan terintegrasi ke dalam semua kegiatan perusahaan. Penelitian ini akan mengambil studi kasus di sebuah perusahaan jasa konsultasi di yogyakarta.

Penelitian sebelumnya yang dilakukan oleh Febrianti dan Hidayanto, 2012, dengan judul penelitian manajemen risiko pada pengelolaan data di bagian pengolahan data PT Petrokimia Gresik. Dewi, 2012, meneliti tentang penerapan sistem manajemen risiko pada industri nasional sebagai masukan untuk program PLTN. Abisay dan Nurhadi (2013), meneliti tentang manajemen risiko pada Bandara Soekarno Hatta berbasis ISO 31000.

Penelitian ini berbeda dengan penelitian sebelumnya dikarenakan penelitian sebelumnya menggunakan ISO 31000:2009 sedangkangkan penelitian ini menggunakan ISO 31000:2018.

Manajemen risiko adalah pendekatan terstruktur dalam mengelola ketidakpastian terkait ancaman, yang merupakan serangkaian aktivitas manusia termasuk penilaian risiko, mengembangkan strategi untuk mengelolanya, dan memitigasi risiko menggunakan manajemen sumber daya (Driantami, Suprapto, \& Perdanakusuma, 2018).

Manajemen risiko adalah seperangkat kebijakan dan prosedur yang dimiliki oleh suatu organisasi untuk mengelola, memantau, dan mengendalikan organisasi terhadap risiko (SBC Warburg, 2004). 
Enterprise Risk Management adalah kerangka kerja yang komprehensif dan terintegrasi untuk mengelola risiko, risiko pasar, modal ekonomi, transfer risiko, untuk memaksimalkan nilai perusahaan (Lam, \& James, 2004).

Manajemen risiko bertujuan untuk mengelola risiko-risiko ini sehingga hasil yang optimal dapat diperoleh. Dalam konteks organisasi, organisasi juga akan menghadapi banyak risiko. Jika organisasi tidak dapat mengelola risiko dengan baik, maka organisasi dapat mengalami kerugian yang signifikan. Oleh karena itu risiko yang dihadapi oleh organisasi juga harus dikelola sehingga organisasi dapat bertahan, atau mungkin mengoptimalkan risiko (Doherty \& Neil, 2000).

Pada 13 November 2009 standar internasional ISO 31000 diterbitkan oleh The International Organization for Standardization dapat digunakan oleh segala jenis organisasi dalam menghadapi berbagai risiko yang melekat pada aktivitas organisasi. ISO 31000 menyediakan prinsip, kerangka kerja, dan proses manajemen risiko yang dapat digunakan sebagai arsitektur manajemen risiko dalam usaha menjamin penerapan manajemen risiko yang efektif (ISO 31000, 2009).

Satu hal yang membedakan ISO 31000 dengan standar manajemen risiko yang lain adalah perspektif ISO 31000 yang lebih luas dan lebih konseptual dibandingkan dengan yang lainnya. Hal ini ditandai dengan adanya kerangka kerja manajemen risiko yang merupakan implementasi prinsip manajemen mutu dan dikenal dengan "Plan-DoCheckAction". Dalam kerangka kerja manajemen risiko, hal ini dinyatakan dengan perencanaan kerangka kerja manajemen risiko, penerapan manajemen risiko, monitoring dan review, serta perbaikan berkelanjutan (Driantami, Suprapto, \& Perdanakusuma, 2018).

ISO 31000:2018 adalah panduan penerapan risiko yang terdiri atas tiga elemen: prinsip (principle), kerangka kerja (framework), dan proses (process). Prinsip manajemen risiko adalah dasar praktik atau filosofi manajemen risiko. Kerangka kerja adalah pengaturan sistem manajemen risiko secara terstruktur dan sistematis di seluruh organisasi. Proses adalah aktivitas pengelolaan risiko yang berurutan dan saling terkait. (IBFGInstitute, 2018).

\section{Metodologi}

Metode dalam penelitian ini menggunakan pendekatan ISO 31000: 2018. Objek penelitian ini adalah perusahaan PT. $\mathrm{ABC}$ yang bergerak di bidang jasa konsultasi di Yogyakarta. Penelitian ini dilakukan dalam beberapa tahap sesuai dengan ISO 31000: 2018 yaitu: prinsip, kerangka kerja, dan proses (Mahardika, Wijaya, \& Cahyono, 2019).

\subsection{Prinsip (Principle)}

Prinsip manjemen yang menjadi dasar seluruh aktivitas internal dan eksternal Perusahaan Jasa Konsultasi yakni:

\subsubsection{Strategy \& Governance}

Menurut Siagian, serangkaian keputusan dan tindakan mendasar yang dibuat oleh manajemen puncak dan dilaksanakan oleh semua tingkatan organisasi untuk mencapai tujuan organisasi (Pelajaran, 2017).

\subsubsection{Business processes}

Menurut Hughes dan Kapoor, "Bisnis adalah organisasi yang menyediakan barang atau jasa untuk belajar untung". Sejalan dengan pemahaman sebelumnya, di sini bisnis adalah organisasi yang menghasilkan barang dan jasa untuk menghasilkan keuntungan (Science Trend, 2016).

\subsubsection{Structure}

Menurut Robbins dan Coulter, struktur organisasi dapat diartikan sebagai kerangka kerja organisasi formal di mana beban kerja dibagi, dikelompokkan, dan dikoordinasikan (Onoini, 2019).

\subsubsection{People}

Karyawan yang terlibat dalam semua kegiatan dalam produksi dan layanan diharapkan untuk bergerak secara efektif dan efisien. 


\subsubsection{Technology}

Menurut Ridwan Sanjaya dan Josua Tarigan, kegiatan pemasaran termasuk branding yang menggunakan berbagai media berbasis web seperti blog, situs web, email, Adwords, dan jejaring sosial (Dosen Pendidikan, 2019).

\subsection{Kerangka kerja (Framework)}

Penelitian ini mengadopsi kerangka kerja perusahaan PwC yang diimplementasikan di perusahaan PT. ABC, seperti yang ditunjukkan pada Gambar 1 dan Gambar 2, adalah kerangka kerja yang digunakan oleh para peneliti untuk mengelola manajemen risiko di PT. ABC.

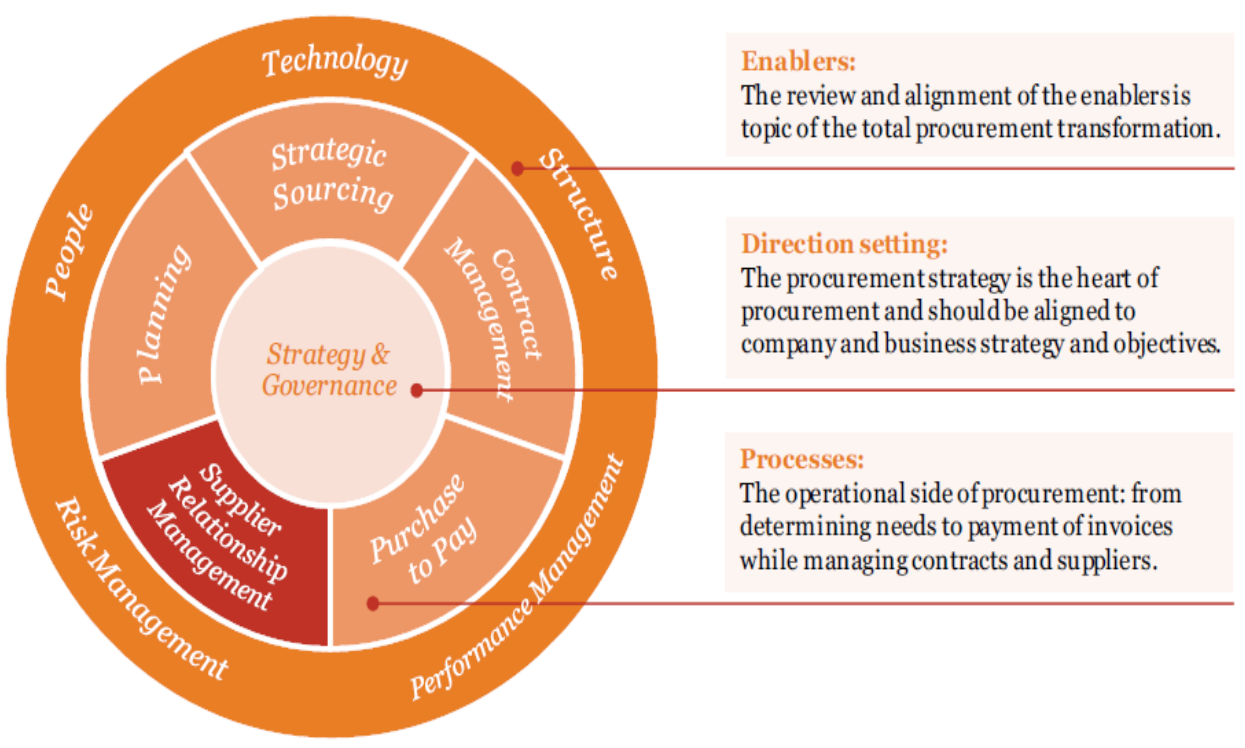

Gambar 1. Framework of PwC

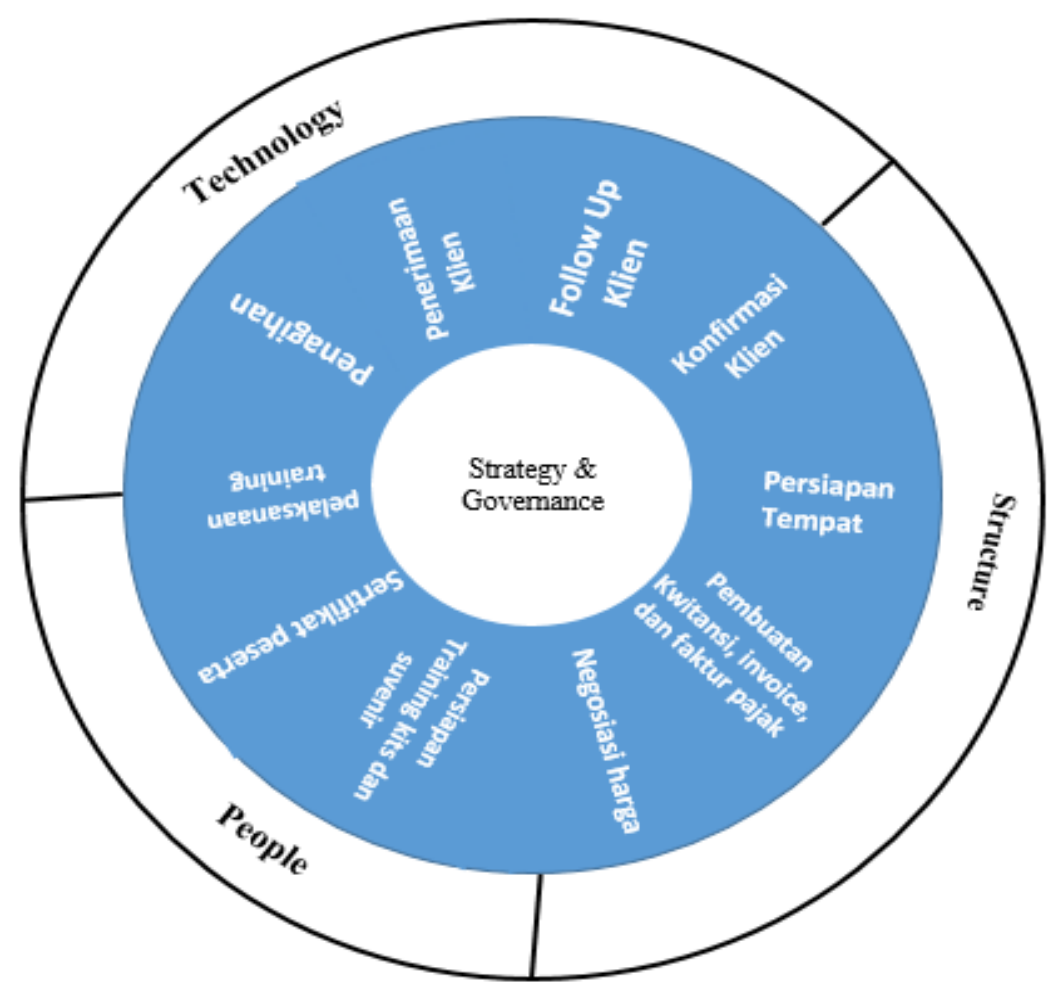

Gambar 2. Framework Aktifitas Perusahaan jasa konsultasi 


\subsection{Proses (Process)}

2.3.1 Penentuan kriteria berdasarkan KPI dengan cara wawancara ke pihak perusahaa untuk mengetahui KPI yang telah ditentukan oleh masing-masing devisi.

2.3.2 Pengumpulan data dengan menyebar kuisioner ke perusahaan.

2.3.3 Identifikasi risiko; mengidentifikasi risiko yang terjadi dan dapat mempengaruhi pencapaian tujuan organisasi.

2.3.4 Analisis risiko; menganalisis kemungkinan dan konsekuensi dari risiko yang telah diidentifikasi.

Tabel 1. Tingkat Probabilitas Risiko

\begin{tabular}{|c|c|c|}
\hline Skala & Keterangan & Tingkat probabilitas \\
\hline 1 & $\begin{array}{c}\text { Sangat } \\
\text { Jarang }\end{array}$ & 1 kali dalam 3 bulan \\
\hline 2 & Jarang & 2 kali dalam 3 bulan \\
\hline 3 & Mungkin & 3 kali dalam 3 bulan \\
\hline 4 & Sering & $5-6$ kali dalam 3 bulan \\
\hline 5 & $\begin{array}{l}\text { Sangat } \\
\text { Sering }\end{array}$ & >7 kali dalam 3 bulan \\
\hline
\end{tabular}

Tabel 2. Tingkat Dampak Risiko

\begin{tabular}{|c|c|c|}
\hline Skala & Keterangan & Tingkat Dampak \\
\hline 1 & $\begin{array}{c}\text { Sanagat } \\
\text { Kecil }\end{array}$ & $\begin{array}{l}\text { Tidak berpengaruh } \\
\text { terhadap perusahaan }\end{array}$ \\
\hline 2 & Kecil & $\begin{array}{l}\text { Berpengaruh kecil tetapi } \\
\text { dapat diabaikan }\end{array}$ \\
\hline 3 & Normal & $\begin{array}{l}\text { Berpengaruh normal } \\
\text { terhadap perusahaan dan } \\
\text { perlu diperhatikan }\end{array}$ \\
\hline 4 & Besar & $\begin{array}{lr}\text { Berpengaruh } & \text { signifikan } \\
\text { terhadap } & \text { perusahaan } \\
\text { dapat } & \text { merugikan } \\
\text { perusahaan } & \end{array}$ \\
\hline 5 & $\begin{array}{l}\text { Sangat } \\
\text { Besar }\end{array}$ & $\begin{array}{l}\text { Sangat berpengaruh dan } \\
\text { sangat merugikan untuk } \\
\text { perusahaan yang } \\
\text { menjadi prioritas paling } \\
\text { utama }\end{array}$ \\
\hline
\end{tabular}

Tabel 3. Tingkat Nilai Risiko

\begin{tabular}{cc}
\hline Skala & Keterangan \\
\hline $1-4$ & Rendah \\
$5-8$ & Sedang \\
$9-12$ & Tinggi \\
\hline
\end{tabular}

Hasil selanjutnya dari analisis risiko adalah tingkat risiko (level of risk) kemudian di buat risk mapping.

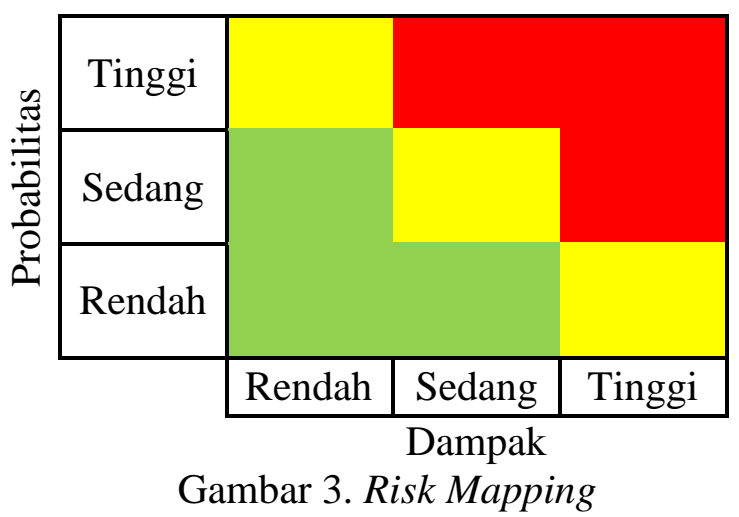

Ket :

$\begin{array}{ll}\text { Merah } & \text { : Posisi Resiko Tinggi } \\ \text { Kuning } & \text { : Posisi Resiko Sedang } \\ \text { Hijau } & \text { : Posisi Resiko Rendah }\end{array}$

Evaluasi risiko; bandingkan hasil analisis risiko dengan kriteria risiko untuk mengetahui apakah risiko dan ukurannya dapat diterima dan ditoleransi. Evaluasi risiko akan membantu menentukan perlakuan risiko

\section{Hasil dan Pembahasan \\ 3.1. Identifikasi Risiko}

Proses identifikasi dilakukan dengan wawancara langsung dengan perusahaan di masing-masing divisi untuk menentukan KPI berdasarkan kerangka kerja. Identifikasi risiko didasarkan pada KPI (tabel 4) yang diperoleh dari perusahaan dan mendistribusikan kuesioner dengan pertanyaan yang sama "apakah risiko ini pernah terjadi dan kemudian menjadi peristiwa risiko (tabel 5).

Tabel 4. Identifikasi KPI berdasarkan Framework

\begin{tabular}{llll}
\hline No & Framework & Kode & KPI \\
\hline 1 & $\begin{array}{l}\text { Strategy \& } \\
\text { Governance }\end{array}$ & A01 & $\begin{array}{l}\text { Karyawan paham } \\
\text { dengan strategi } \\
\text { perusahaan }\end{array}$ \\
\cline { 3 - 4 } & & A02 & $\begin{array}{l}\text { Karyawan } \\
\text { bertindak sesuai } \\
\text { strategi yang } \\
\text { diterapkan }\end{array}$ \\
& & A03 & $\begin{array}{l}\text { Evaluasi rutin } \\
\text { strategi yang } \\
\text { terdokumentasi }\end{array}$
\end{tabular}




\begin{tabular}{|c|c|c|c|}
\hline & & \\
\hline & & A04 & $\begin{array}{l}\text { Jumlah rapat yang } \\
\text { terkoordinasi } \\
\text { perbulannya untuk } \\
\text { startegi perusahaan }\end{array}$ \\
\hline 2 & Proses Bisnis & & \\
\hline \multirow[t]{2}{*}{2.1} & \multirow[t]{2}{*}{$\begin{array}{l}\text { Penerimaan } \\
\text { Klien }\end{array}$} & A05 & $\begin{array}{l}\text { Data Klien \& } \\
\text { Perusahaan }\end{array}$ \\
\hline & & A06 & Jenis Training \\
\hline \multirow[t]{3}{*}{2.2} & \multirow{3}{*}{$\begin{array}{l}\text { Follow Up } \\
\text { Klien }\end{array}$} & A07 & Waktu respon \\
\hline & & A08 & Selles Call \\
\hline & & A09 & Prospek \\
\hline \multirow[t]{3}{*}{2.3} & \multirow[t]{3}{*}{$\begin{array}{l}\text { Konfirmasi } \\
\text { Klien }\end{array}$} & A10 & $\begin{array}{l}\text { Formulir } \\
\text { Konfirmasi }\end{array}$ \\
\hline & & A11 & Deal Training \\
\hline & & A12 & Jumlah Peserta \\
\hline \multirow[t]{2}{*}{2.4} & \multirow{2}{*}{$\begin{array}{l}\text { Persiapan } \\
\text { Tempat } \\
\text { Training }\end{array}$} & A13 & $\begin{array}{l}\text { Kontak ke selles } \\
\text { hotel }\end{array}$ \\
\hline & & A14 & $\begin{array}{l}\text { Deal harga dan } \\
\text { location }\end{array}$ \\
\hline \multirow[t]{3}{*}{2.5} & \multirow{3}{*}{$\begin{array}{l}\text { Pembuatan } \\
\text { Kwitansi, } \\
\text { Invoice dan } \\
\text { Pajak }\end{array}$} & A15 & Data dari marketing \\
\hline & & A16 & Invoice \\
\hline & & A17 & Kwitansi \\
\hline \multirow[t]{4}{*}{2.6} & \multirow{4}{*}{$\begin{array}{l}\text { Negosiasi } \\
\text { Harga }\end{array}$} & A18 & Deal harga Training \\
\hline & & A19 & Silabus \\
\hline & & A20 & $\begin{array}{l}\text { Konfirmasi } \\
\text { Instruktur }\end{array}$ \\
\hline & & A21 & Materi Training \\
\hline \multirow[t]{2}{*}{2.7} & \multirow{2}{*}{$\begin{array}{l}\text { Persiapan } \\
\text { Training Kits } \\
\text { dan Sovenir }\end{array}$} & A22 & Data Peserta \\
\hline & & $\mathrm{A} 23$ & $\begin{array}{l}\text { Jumlah Training } \\
\text { Kits \& Sovenir }\end{array}$ \\
\hline \multirow[t]{3}{*}{2.8} & \multirow[t]{3}{*}{$\begin{array}{l}\text { Sertivikat } \\
\text { Peserta }\end{array}$} & A24 & $\begin{array}{l}\text { Data peserta } \\
\text { training }\end{array}$ \\
\hline & & $\mathrm{A} 25$ & $\begin{array}{l}\text { Deal harga } \\
\text { Sertivikat }\end{array}$ \\
\hline & & A26 & Jumlah peserta \\
\hline \multirow[t]{3}{*}{2.9} & \multirow{3}{*}{$\begin{array}{l}\text { Pelaksanaan } \\
\text { Training }\end{array}$} & A27 & Tepat waktu \\
\hline & & A28 & $\begin{array}{l}\text { Cetak Sertivikat } \\
\text { sesuai data }\end{array}$ \\
\hline & & A29 & From Evaluasi \\
\hline 2.10 & $\begin{array}{l}\text { Penagihan } \\
\text { Biaya }\end{array}$ & A30 & $\begin{array}{l}\text { Data Penagihan ke } \\
\text { Klien }\end{array}$ \\
\hline \multirow[t]{3}{*}{3} & \multirow[t]{3}{*}{ Structure } & A31 & $\begin{array}{l}\text { Efektifitas struktur } \\
\text { organisasi } \\
\text { perusahaan }\end{array}$ \\
\hline & & A32 & $\begin{array}{l}\text { Kejelasan tugas dan } \\
\text { tanggung jawab }\end{array}$ \\
\hline & & A33 & Rapat evaluasi rutin \\
\hline \multirow[t]{4}{*}{4} & \multirow[t]{4}{*}{ People } & A34 & $\begin{array}{l}\text { Kemudahan untuk } \\
\text { dihubungi }\end{array}$ \\
\hline & & A35 & $\begin{array}{l}\text { Ketersediaaan } \\
\text { untuk membantu }\end{array}$ \\
\hline & & A36 & $\begin{array}{l}\text { Jumlah Keluhan } \\
\text { terhadap operasioal } \\
\text { training }\end{array}$ \\
\hline & & A37 & Kepuasan Pegawai \\
\hline 5 & Tecnology & A38 & $\begin{array}{l}\text { Jumlah medsos } \\
\text { yang digunakan }\end{array}$ \\
\hline
\end{tabular}

\begin{tabular}{ll}
\hline A39 & $\begin{array}{l}\text { Efektifitas medsos } \\
\text { yang digunakan }\end{array}$ \\
\hline A40 & $\begin{array}{l}\text { Kecanggihan IT } \\
\text { yang digunakan }\end{array}$ \\
\hline
\end{tabular}

\subsection{Risk Event berdasarkan KPI}

Tabel 5. Risk Event

\begin{tabular}{|c|c|c|}
\hline Kode & KPI & Risk Event \\
\hline A01 & $\begin{array}{l}\text { Karyawan paham } \\
\text { dengan strategi } \\
\text { perusahaan }\end{array}$ & $\begin{array}{l}\text { Karyawan tidak } \\
\text { memahami strategi } \\
\text { perusahaan secara } \\
\text { menyeluruh }\end{array}$ \\
\hline A02 & $\begin{array}{l}\text { Karyawan } \\
\text { bertindak sesuai } \\
\text { strategi yang } \\
\text { diterapkan }\end{array}$ & $\begin{array}{l}\text { Karyawan tidak } \\
\text { bertindak sesuai } \\
\text { strategi yang } \\
\text { diterapkan } \\
\text { perusahaan }\end{array}$ \\
\hline $\mathrm{A} 03$ & $\begin{array}{l}\text { Evaluasi rutin } \\
\text { strategi yang } \\
\text { terdokumentasi }\end{array}$ & $\begin{array}{l}\text { Adanya evaluasi yang } \\
\text { tidak terdokumentasi }\end{array}$ \\
\hline A04 & $\begin{array}{l}\text { Jumlah rapat yang } \\
\text { terkoordinasi } \\
\text { perbulannya untuk } \\
\text { startegi perusahaan }\end{array}$ & $\begin{array}{l}\text { Tidak tercapainya } \\
\text { jumlah rapat yang di } \\
\text { tentukan dalam } \\
\text { perbulannya }\end{array}$ \\
\hline A05 & $\begin{array}{l}\text { Data Klien \& } \\
\text { Perusahaan }\end{array}$ & $\begin{array}{l}\text { Data klien dan } \\
\text { perusahaan yang } \\
\text { tidak jelas/ lengkap. }\end{array}$ \\
\hline A06 & Jenis Training & $\begin{array}{l}\text { permintaan jenis } \\
\text { training yang belum } \\
\text { pernah d trainingkan. }\end{array}$ \\
\hline A07 & Waktu respon & $\begin{array}{l}\text { Respon yang } \\
\text { terlambat dan lama } \\
\text { saat menerima email } \\
\text { dari klien. }\end{array}$ \\
\hline A08 & Selles Call & $\begin{array}{l}\text { Kurang komunikatif } \\
\text { sehingga klien tidak } \\
\text { tertarik. }\end{array}$ \\
\hline A09 & Prospek & $\begin{array}{l}\text { Tidak terjadinya } \\
\text { kesepakatan dengan } \\
\text { klien }\end{array}$ \\
\hline A10 & $\begin{array}{l}\text { Formulir } \\
\text { Konfirmasi }\end{array}$ & $\begin{array}{l}\text { Formulir konfirmasi } \\
\text { terlambat di kirim. }\end{array}$ \\
\hline A11 & Deal Training & $\begin{array}{l}\text { Tidak terjadinya kata } \\
\text { deal. }\end{array}$ \\
\hline A12 & Jumlah Peserta & $\begin{array}{l}\text { Jumlah peserta yang } \\
\text { tidak jelas jumlahnya. }\end{array}$ \\
\hline A13 & $\begin{array}{l}\text { Kontak ke selles } \\
\text { hotel }\end{array}$ & $\begin{array}{l}\text { Hotel dan tempat } \\
\text { penuh dan harga } \\
\text { tinggi. }\end{array}$ \\
\hline A14 & $\begin{array}{l}\text { Deal harga dan } \\
\text { location }\end{array}$ & $\begin{array}{l}\text { Tidak dealnya harga } \\
\text { dan lokasi oleh klien }\end{array}$ \\
\hline A15 & Data dari marketing & $\begin{array}{l}\text { Data yang terlambat } \\
\text { dikirim }\end{array}$ \\
\hline A16 & Invoice & $\begin{array}{l}\text { Terlambatnya } \\
\text { pengiriman invoice } \\
\text { ke klien }\end{array}$ \\
\hline A17 & Kwitansi & Kwitansi yang tidak \\
\hline
\end{tabular}




\begin{tabular}{|c|c|c|}
\hline & & $\begin{array}{l}\text { sesuai karna ketukar } \\
\text { dengan klien lain }\end{array}$ \\
\hline A18 & Deal harga Training & $\begin{array}{l}\text { Harga training yang } \\
\text { tinggi sehingga klien } \\
\text { keberatan }\end{array}$ \\
\hline A19 & Silabus & $\begin{array}{l}\text { Silabus yang tidak } \\
\text { update }\end{array}$ \\
\hline A20 & $\begin{array}{l}\text { Konfirmasi } \\
\text { Instruktur }\end{array}$ & $\begin{array}{l}\text { Harga instruktur yang } \\
\text { tinggi }\end{array}$ \\
\hline A21 & Materi Training & $\begin{array}{l}\text { Materi training yang } \\
\text { tidak update }\end{array}$ \\
\hline A22 & Data Peserta & $\begin{array}{l}\text { Data peserta yang } \\
\text { berubah -ubah }\end{array}$ \\
\hline A23 & $\begin{array}{l}\text { Jumlah Training } \\
\text { Kits \& Sovenir }\end{array}$ & $\begin{array}{l}\text { Kehabisan stok } \\
\text { training kits dan } \\
\text { sovenir }\end{array}$ \\
\hline A24 & $\begin{array}{l}\text { Data peserta } \\
\text { training }\end{array}$ & $\begin{array}{l}\text { Nama yang tidak } \\
\text { sesuai sehingga salah } \\
\text { pengetikan }\end{array}$ \\
\hline A25 & $\begin{array}{l}\text { Deal harga } \\
\text { Sertivikat }\end{array}$ & $\begin{array}{l}\text { Harga sertifikat yang } \\
\text { tidak sesuai }\end{array}$ \\
\hline A26 & Jumlah peserta & $\begin{array}{l}\text { Jumah peserta yang } \\
\text { bertambah sehingga } \\
\text { data belum masuk } \\
\text { untuk pembuatan } \\
\text { sertifikat }\end{array}$ \\
\hline A27 & Tepat waktu & $\begin{array}{l}\text { Terlambatnya } \\
\text { pelaksanaan training } \\
\text { tidak sesuai dengan } \\
\text { waktu yang } \\
\text { ditentukan }\end{array}$ \\
\hline A28 & $\begin{array}{l}\text { Cetak Sertivikat } \\
\text { sesuai data }\end{array}$ & $\begin{array}{l}\text { Data yang masuk } \\
\text { berbeda dari nama } \\
\text { dan gelar saat di } \\
\text { cetak }\end{array}$ \\
\hline A29 & From Evaluasi & $\begin{array}{l}\text { From evaluasi yang } \\
\text { kurang }\end{array}$ \\
\hline A30 & $\begin{array}{l}\text { Data Penagihan ke } \\
\text { Klien }\end{array}$ & $\begin{array}{l}\text { Terlambatnya } \\
\text { pengiriman } \\
\text { penagihan ke klien. }\end{array}$ \\
\hline A31 & $\begin{array}{l}\text { Efektifitas struktur } \\
\text { organisasi } \\
\text { perusahaan }\end{array}$ & $\begin{array}{l}\text { Ketidakpahaman atas } \\
\text { organisasi perusahaan } \\
\text { sehingga terjadi } \\
\text { kekurangan } \\
\text { efektifitas }\end{array}$ \\
\hline A32 & $\begin{array}{l}\text { Kejelasan tugas dan } \\
\text { tanggung jawab }\end{array}$ & $\begin{array}{l}\text { Adanya tumpang } \\
\text { tindih tugas dan } \\
\text { tanggung jawab }\end{array}$ \\
\hline A33 & Rapat evaluasi rutin & $\begin{array}{l}\text { Tidak terjadinya rapat } \\
\text { evaluasi rutin karna } \\
\text { suatu hal }\end{array}$ \\
\hline A34 & $\begin{array}{l}\text { Kemudahan untuk } \\
\text { dihubungi }\end{array}$ & $\begin{array}{l}\text { Klien yang tidak } \\
\text { mudah dihubungi }\end{array}$ \\
\hline A35 & $\begin{array}{l}\text { Ketersediaaan } \\
\text { untuk membantu }\end{array}$ & $\begin{array}{l}\text { Kurang } \\
\text { kooperativenya } \\
\text { semua bagian saat } \\
\text { proses penerimaan } \\
\text { klien hingga } \\
\text { pelaksanaan training. }\end{array}$ \\
\hline
\end{tabular}

\begin{tabular}{lll}
\hline A36 & $\begin{array}{l}\text { Jumlah Keluhan } \\
\text { terhadap operasioal } \\
\text { training (Skala) }\end{array}$ & $\begin{array}{l}\text { Penanganan keluhan } \\
\text { klien lambat }\end{array}$ \\
\hline A37 & Kepuasan Pegawai & $\begin{array}{l}\text { Ruang kerja yang } \\
\text { tidak nyaman. Tidak } \\
\text { adanya impact dari } \\
\text { hasil pekerjaan yang } \\
\text { diperoleh }\end{array}$ \\
\hline A38 & $\begin{array}{l}\text { Jumlah medsos } \\
\text { yang digunakan }\end{array}$ & $\begin{array}{l}\text { Jumlah medsos yang } \\
\text { tersebar tidak sesuai } \\
\text { target }\end{array}$ \\
\hline A39 & $\begin{array}{l}\text { Efektifitas medsos } \\
\text { yang digunakan }\end{array}$ & $\begin{array}{l}\text { Medsos yang di sebar } \\
\text { dan dibuat kurang } \\
\text { menarik klien }\end{array}$ \\
\hline A40 & $\begin{array}{l}\text { Kecanggihan IT } \\
\text { yang digunakan }\end{array}$ & $\begin{array}{l}\text { IT yang digunakan } \\
\text { sering error }\end{array}$ \\
\hline
\end{tabular}

\subsection{Analisis Risiko}

Analisis dilakukan dengan menyebarkan kuesioner dan mewawancarai setiap divisi di perusahaan PT. ABC untuk mengetahui seberapa besar probabilitas dan dampak risiko yang terjadi sesuai tabel di bawah ini.

Tabel. 6. Probabilitas, Dampak

\begin{tabular}{|c|c|c|c|c|c|}
\hline No & Risk Event & Pro & Dam & N.Res & Kode \\
\hline 1 & $\begin{array}{l}\text { Karyawan tidak } \\
\text { memahami strategi } \\
\text { perusahaan secara } \\
\text { menyeluruh }\end{array}$ & 3 & 3 & 9 & A1 \\
\hline 2 & $\begin{array}{lr}\text { Karyawan } & \text { tidak } \\
\text { bertindak } & \text { sesuai } \\
\text { strategi } & \text { yang } \\
\text { diterapkan } & \\
\text { perusahaan } & \\
\end{array}$ & 3 & 2 & 6 & $\mathrm{~A} 2$ \\
\hline 3 & $\begin{array}{lr}\text { Adanya } & \text { evaluasi } \\
\text { yang } & \text { tidak } \\
\text { terdokumentasi }\end{array}$ & 3 & 3 & 9 & A3 \\
\hline 4 & $\begin{array}{l}\text { Tidak tercapainya } \\
\text { jumlah rapat yang } \\
\text { di tentukan dalam } \\
\text { perbulannya }\end{array}$ & 3 & 3 & 9 & A4 \\
\hline 5 & $\begin{array}{lr}\text { Data klien } & \text { dan } \\
\text { perusahaan } & \text { yang } \\
\text { tidak } & \text { jelas/ } \\
\text { lengkap. } & \\
\end{array}$ & 3 & 3 & 9 & A5 \\
\hline 6 & $\begin{array}{l}\text { permintaan jenis } \\
\text { training yang } \\
\text { belum pernah d } \\
\text { trainingkan. }\end{array}$ & 3 & 3 & 9 & A6 \\
\hline 7 & $\begin{array}{lr}\text { Respon } & \text { yang } \\
\text { terlambat } & \text { dan } \\
\text { lama } & \text { saat } \\
\text { menerima } & \text { email } \\
\text { dari klien. } & \\
\end{array}$ & 3 & 2 & 6 & A7 \\
\hline 8 & $\begin{array}{ll}\text { Kurang } & \\
\text { komunikatif } \\
\text { sehingga } \quad \text { klien }\end{array}$ & 3 & 2 & 6 & A8 \\
\hline
\end{tabular}




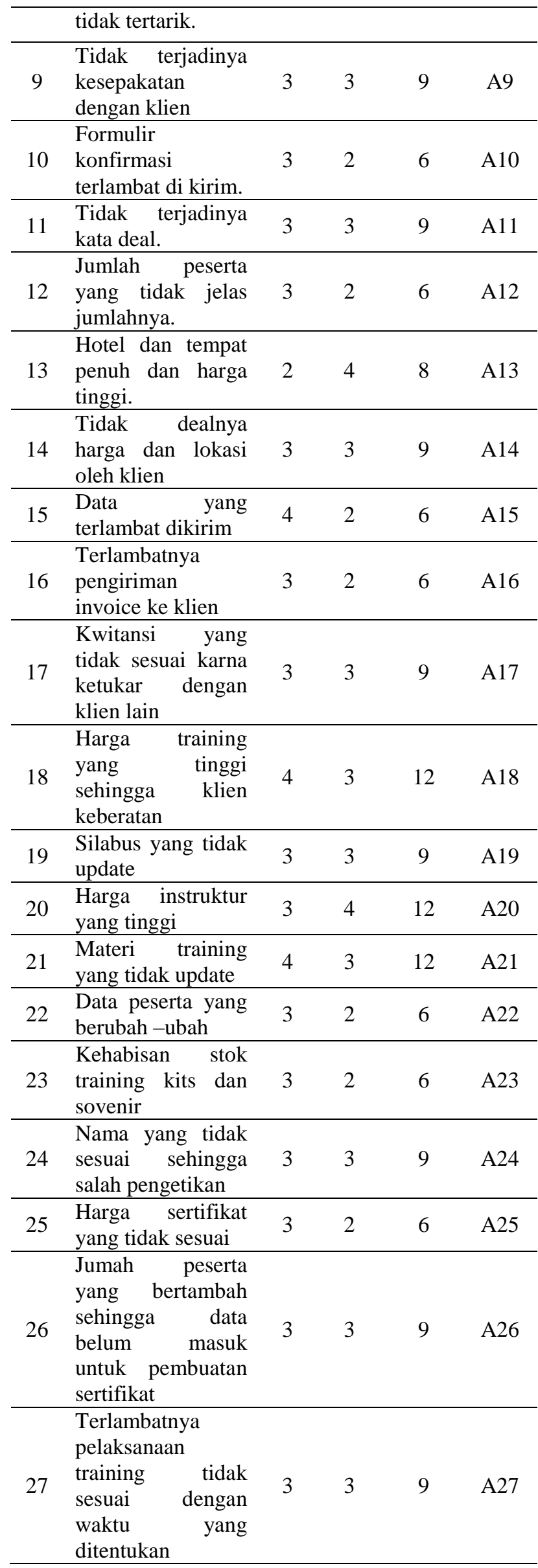

\begin{tabular}{|c|c|c|c|c|c|}
\hline 28 & $\begin{array}{l}\text { Data yang masuk } \\
\text { berbeda dari nama } \\
\text { dan gelar saat d } \\
\text { cetak }\end{array}$ & 3 & 3 & 9 & A28 \\
\hline 29 & $\begin{array}{l}\text { From evaluasi } \\
\text { yang kurang }\end{array}$ & 3 & 2 & 6 & A29 \\
\hline 30 & $\begin{array}{l}\text { Terlambatnya } \\
\text { pengiriman } \\
\text { penagihan ke } \\
\text { klien. }\end{array}$ & 3 & 2 & 6 & A30 \\
\hline 31 & $\begin{array}{l}\text { Ketidakpahaman } \\
\text { atas organisasi } \\
\text { perusahaan } \\
\text { sehingga terjadi } \\
\text { kekurangan } \\
\text { efektifitas }\end{array}$ & 3 & 2 & 6 & A31 \\
\hline 32 & $\begin{array}{l}\text { Adanya tumpang } \\
\text { tindih tugas dan } \\
\text { tanggung jawab }\end{array}$ & 2 & 4 & 8 & A 32 \\
\hline 33 & 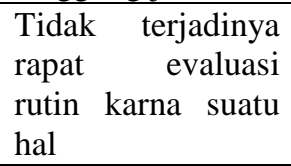 & 4 & 2 & 8 & A33 \\
\hline 34 & $\begin{array}{l}\text { Klien yang tidak } \\
\text { mudah dihubungi }\end{array}$ & 3 & 3 & 9 & A34 \\
\hline 35 & $\begin{array}{l}\text { Kurang } \\
\text { kooperativenya } \\
\text { semua bagian saat } \\
\text { proses penerimaan } \\
\text { klien hingga } \\
\text { pelaksanaan } \\
\text { training. }\end{array}$ & 3 & 3 & 9 & A35 \\
\hline 36 & $\begin{array}{l}\text { Penanganan } \\
\text { keluhan } \\
\text { lambat }\end{array}$ & 4 & 3 & 12 & A36 \\
\hline 37 & $\begin{array}{l}\text { Ruang kerja yang } \\
\text { tidak nyaman } \\
\text { sehingga tidak } \\
\text { adanya impact dari } \\
\text { hasil pekerjaan } \\
\text { yang diperoleh }\end{array}$ & 4 & 3 & 12 & A 37 \\
\hline 38 & $\begin{array}{l}\text { Jumlah medsos } \\
\text { yang tersebar tidak } \\
\text { sesuai target }\end{array}$ & 3 & 3 & 9 & A38 \\
\hline 39 & $\begin{array}{l}\text { Medsos yang di } \\
\text { sebar dan dibuat } \\
\text { kurang menarik } \\
\text { klien }\end{array}$ & 3 & 3 & 9 & A39 \\
\hline 40 & $\begin{array}{l}\text { IT yang digunakan } \\
\text { sering error }\end{array}$ & 3 & 3 & 9 & A40 \\
\hline
\end{tabular}

\subsection{Kriteria Resiko Berdasarkan Iso 31000}

Probabilitas, dampak dan nilai risiko telah diketahui kemudian dikriteriakan berdasarkan ISO 31000 seperti tabel di bawah ini. 
Tabel. 7. Nilai Risiko

\begin{tabular}{ccccc}
\hline Kode & Pro & Dam & N.Res & $\begin{array}{c}\text { Kriteria } \\
\text { Resiko }\end{array}$ \\
\hline A1 & 3 & 3 & 9 & Besar \\
A2 & 3 & 2 & 6 & Sedang \\
A3 & 3 & 3 & 9 & Besar \\
A4 & 3 & 3 & 9 & Besar \\
A5 & 3 & 3 & 9 & Besar \\
A6 & 3 & 3 & 9 & Besar \\
A7 & 3 & 2 & 6 & Sedang \\
A8 & 3 & 2 & 6 & Sedang \\
A9 & 3 & 3 & 9 & Besar \\
A10 & 3 & 2 & 6 & Sedang \\
A11 & 3 & 3 & 9 & Besar \\
A12 & 3 & 2 & 6 & Sedang \\
A13 & 2 & 4 & 8 & Sedang \\
A14 & 3 & 3 & 9 & Besar \\
A15 & 4 & 2 & 6 & Sedang \\
A16 & 3 & 2 & 6 & Sedang \\
A17 & 3 & 3 & 9 & Besar \\
A18 & 4 & 3 & 12 & Besar \\
A19 & 3 & 3 & 9 & Besar \\
A20 & 3 & 4 & 12 & Besar \\
A21 & 4 & 3 & 12 & Besar \\
A22 & 3 & 2 & 6 & Sedang \\
A23 & 3 & 2 & 6 & Sedang \\
A24 & 3 & 3 & 9 & Besar \\
A25 & 3 & 2 & 6 & Sedang \\
A26 & 3 & 3 & 9 & Besar \\
A27 & 3 & 3 & 9 & Besar \\
A28 & 3 & 3 & 9 & Besar \\
A29 & 3 & 2 & 6 & Sedang \\
A30 & 3 & 2 & 6 & Sedang \\
A31 & 3 & 2 & 6 & Sedang \\
A32 & 2 & 4 & 8 & Sedang \\
A33 & 4 & 2 & 8 & Sedang \\
A34 & 3 & 3 & 9 & Besar \\
A35 & 3 & 3 & 9 & Besar \\
A36 & 4 & 3 & 12 & Besar \\
A37 & 4 & 3 & 12 & Besar \\
A38 & 3 & 3 & 9 & Besar \\
A39 & 3 & 3 & 9 & Besar \\
A40 & 3 & 3 & 9 & Besar \\
\hline & & & &
\end{tabular}

\subsection{Risk Mapping}

Pemetaan risiko dilakukan untuk menentukan penyebaran risiko yang terjadi mulai dari kode A1 - A40 seperti yang ditunjukkan di bawah ini.

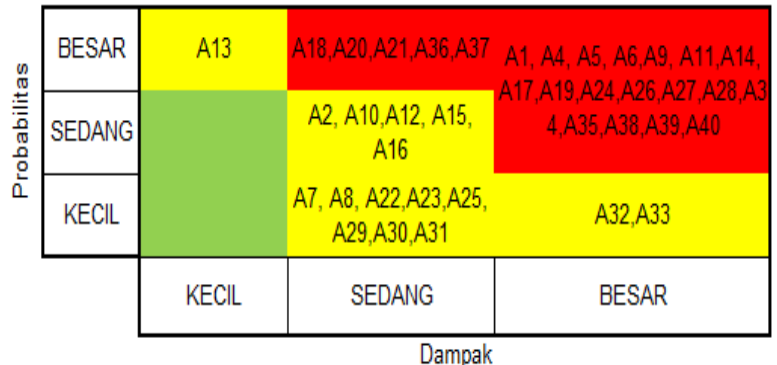

Gambar 4. Risk Mapping

Dapat dilihat dari risk mapping diatas sejumlah aktivitas masih banyak yang berada dalam kondisi sebagai sumber ancaman yang dapat menyebabkan nilai kehilangan yang tinggi pada asset, reputasi organisasi dan sumber daya ((Driantami, Suprapto, \& Perdanakusuma, 2018). Sehingga dilakukan tindakan mitigasi/evaluasi resiko.

\subsection{Evaluasi Resiko}

Evaluasi risiko dilakukan untuk mengoptimalkan risiko yang terjadi dari setiap aktivitas perusahaan dan cara mengelola risiko ini seperti yang ditunjukkan pada tabel 8 .

\begin{tabular}{|c|c|c|c|}
\hline No & Risk Event & $\begin{array}{l}\text { Potential } \\
\text { Impact }\end{array}$ & $\begin{array}{l}\text { Evaluasi } \\
\text { Resiko }\end{array}$ \\
\hline 1 & $\begin{array}{l}\text { Karyawan } \\
\text { tidak } \\
\text { memahami } \\
\text { strategi } \\
\text { perusahaan } \\
\text { secara } \\
\text { menyeluruh }\end{array}$ & $\begin{array}{l}\text { Menurunkan } \\
\text { profit } \\
\text { perusahaan } \\
\text { dan } \\
\text { kepuasan } \\
\text { pelanggan } \\
\text { (klien) }\end{array}$ & $\begin{array}{l}\text { Memberikan } \\
\text { pelatihan } \\
\text { untuk } \\
\text { memahami } \\
\text { strategi serta } \\
\text { melakukan } \\
\text { evaluasi } \\
\text { untuk } \\
\text { pemahaman } \\
\text { strategi } \\
\text { perusahaan }\end{array}$ \\
\hline 2 & $\begin{array}{l}\text { Karyawan } \\
\text { tidak } \\
\text { bertindak } \\
\text { sesuai } \\
\text { strategi } \\
\text { yang } \\
\text { diterapkan } \\
\text { perusahaan }\end{array}$ & $\begin{array}{l}\text { Kinerja yang } \\
\text { diharpakan } \\
\text { perusahaan } \\
\text { tidak } \\
\text { tercapai }\end{array}$ & $\begin{array}{l}\text { Memberikan } \\
\text { sanksi bagi } \\
\text { karyawan } \\
\text { yang tidak } \\
\text { bertindak } \\
\text { sesuai } \\
\text { strategi } \\
\text { perusahaan }\end{array}$ \\
\hline 3 & $\begin{array}{l}\text { Adanya } \\
\text { evaluasi } \\
\text { yang tidak } \\
\text { terdokumen } \\
\text { tasi }\end{array}$ & $\begin{array}{l}\text { Hilangnya } \\
\text { dokumen } \\
\text { dan strategi } \\
\text { yang di } \\
\text { evaluasikan }\end{array}$ & $\begin{array}{l}\text { Membuatka } \\
\mathrm{n} \quad \text { laporan } \\
\text { evaluasi } \\
\text { untuk setiap } \\
\text { dokumentasi } \\
\text { evaluasi } \\
\text { yang } \\
\text { dilakukan }\end{array}$ \\
\hline
\end{tabular}




\begin{tabular}{|c|c|c|c|}
\hline 4 & $\begin{array}{l}\text { Tidak } \\
\text { tercapainya } \\
\text { jumlah } \\
\text { rapat yang } \\
\text { di tentukan } \\
\text { dalam } \\
\text { perbulanny } \\
\text { a }\end{array}$ & $\begin{array}{l}\text { Evalusi } \\
\text { strategi } \\
\text { penanganan } \\
\text { masalah } \\
\text { akan } \\
\text { terlambat }\end{array}$ & $\begin{array}{l}\text { Membuatka } \\
\mathrm{n} \quad \text { from } \\
\text { pelaporan } \\
\text { untuk setiap } \\
\text { devisi untuk } \\
\text { perminggun } \\
\text { ya }\end{array}$ \\
\hline 5 & $\begin{array}{l}\text { Data klien } \\
\text { dan } \\
\text { perusahaan } \\
\text { yang tidak } \\
\text { jelas dan } \\
\text { lengkap. }\end{array}$ & $\begin{array}{l}\text { Devisi } \\
\text { marketing } \\
\text { ragu untuk } \\
\text { menerima } \\
\text { permintaan } \\
\text { training }\end{array}$ & $\begin{array}{l}\text { Membuatka } \\
\mathrm{n} \text { from data } \\
\text { diri untuk } \\
\text { klien }\end{array}$ \\
\hline 6 & $\begin{array}{l}\text { Permintaan } \\
\text { jenis } \\
\text { training } \\
\text { yang belum } \\
\text { pernah di } \\
\text { trainingkan. }\end{array}$ & $\begin{array}{l}\text { Susah } \\
\text { mencari } \\
\text { instruktur } \\
\text { dan harga } \\
\text { training } \\
\text { yang belum } \\
\text { diketahui }\end{array}$ & $\begin{array}{l}\text { Meberikan } \\
\text { daftar jenis } \\
\text { jenis } \\
\text { training ke } \\
\text { klien }\end{array}$ \\
\hline 7 & $\begin{array}{l}\text { Respon } \\
\text { yang } \\
\text { terlambat } \\
\text { dan lama } \\
\text { saat } \\
\text { menerima } \\
\text { email dari } \\
\text { klien. }\end{array}$ & $\begin{array}{l}\text { Hilangnya } \\
\text { klien }\end{array}$ & $\begin{array}{l}\text { Mebuatkan } \\
\text { aplikasi } \\
\text { untuk } \\
\text { merespon } \\
\text { secara } \\
\text { otomatis }\end{array}$ \\
\hline 8 & $\begin{array}{l}\text { Kurang } \\
\text { komunikatif } \\
\text { sehingga } \\
\text { klien tidak } \\
\text { tertarik. }\end{array}$ & $\begin{array}{l}\text { Hilangnya } \\
\text { klien }\end{array}$ & $\begin{array}{l}\text { Memberikan } \\
\text { pelatihan ke } \\
\text { selles call } \\
\text { agar lebih } \\
\text { komunikatif }\end{array}$ \\
\hline 9 & $\begin{array}{l}\text { Tidak } \\
\text { terjadinya } \\
\text { kesepakatan } \\
\text { dengan } \\
\text { klien }\end{array}$ & $\begin{array}{l}\text { Hilangnya } \\
\text { klien }\end{array}$ & $\begin{array}{l}\text { Memberikan } \\
\text { prospek } \\
\text { yang terbaik } \\
\text { dalam } \\
\text { mengfollow } \\
\text { up klien } \\
\end{array}$ \\
\hline 10 & $\begin{array}{l}\text { Formulir } \\
\text { konfirmasi } \\
\text { terlambat di } \\
\text { kirim. }\end{array}$ & $\begin{array}{l}\text { Terlambatya } \\
\text { klien } \\
\text { memberikan } \\
\text { kepastian ke } \\
\text { perusahaan }\end{array}$ & $\begin{array}{l}\text { Memberikan } \\
\text { jangka } \\
\text { waktu klien } \\
\text { untuk } \\
\text { konfirmasi } \\
\text { ke } \\
\text { perusahaan }\end{array}$ \\
\hline 11 & $\begin{array}{l}\text { Tidak } \\
\text { terjadinya } \\
\text { kata deal. }\end{array}$ & $\begin{array}{l}\text { Hilangnya } \\
\text { klien }\end{array}$ & $\begin{array}{l}\text { Meberikan } \\
\text { jangka } \\
\text { waktu untuk } \\
\text { klien } \\
\text { memberikan } \\
\text { keputusan } \\
\end{array}$ \\
\hline 12 & $\begin{array}{l}\text { Jumlah } \\
\text { peserta } \\
\text { yang tidak } \\
\text { jelas } \\
\text { jumlahnya. }\end{array}$ & $\begin{array}{l}\text { Dalam } \\
\text { menentukan } \\
\text { harga dan } \\
\text { tempat }\end{array}$ & $\begin{array}{l}\text { Memberikan } \\
\text { from jumlah } \\
\text { peserta } \\
\text { untuk } \\
\text { mengikuti } \\
\text { training }\end{array}$ \\
\hline
\end{tabular}

\begin{tabular}{|c|c|c|c|}
\hline 13 & $\begin{array}{ll}\text { Hotel dan } \\
\text { tempat } & \\
\text { training } & \\
\text { penuh dan } \\
\text { harga } & \\
\text { tinggi. } & \\
\end{array}$ & $\begin{array}{l}\text { Jadwal dan } \\
\text { rencana } \\
\text { perusahaan } \\
\text { tidak sesuai }\end{array}$ & $\begin{array}{l}\text { Mempersiap } \\
\text { kan bebapa } \\
\text { hotel untuk } \\
\text { cadangan }\end{array}$ \\
\hline 14 & $\begin{array}{lc}\text { Tidak } & \\
\text { dealnya } & \\
\text { harga } & \text { dan } \\
\text { lokasi } & \text { oleh } \\
\text { klien } & \end{array}$ & $\begin{array}{l}\text { Membuat } \\
\text { RAB } \\
\text { kembali oleh } \\
\text { perusahaan }\end{array}$ & $\begin{array}{l}\text { Memberikan } \\
\text { daftar } \\
\text { anggaran } \\
\text { untuk } \\
\text { beberapa } \\
\text { hotel } \\
\text { sehingga } \\
\text { klien bisa } \\
\text { memilihnya }\end{array}$ \\
\hline 15 & $\begin{array}{l}\text { Data yang } \\
\text { terlambat } \\
\text { dikirim dari } \\
\text { marketing }\end{array}$ & $\begin{array}{l}\text { Pembuatan } \\
\text { invoice } \\
\text { terlambat }\end{array}$ & $\begin{array}{l}\text { Meberikan } \\
\text { target untuk } \\
\text { maketing } \\
\text { mengirimka } \\
\mathrm{n} \quad \text { data } \\
\text { sehari/ } \\
\text { hari } \\
\text { sebelumnya }\end{array}$ \\
\hline 16 & $\begin{array}{l}\text { Terlambatn } \\
\text { ya } \\
\text { pengiriman } \\
\text { invoice ke } \\
\text { klien }\end{array}$ & $\begin{array}{l}\text { Klien tidak } \\
\text { menerima } \\
\text { invoice } \\
\text { untuk } \\
\text { agenda } \\
\text { training }\end{array}$ & $\begin{array}{l}\text { Perusahaan } \\
\text { memberikan } \\
\text { sanksi bagi } \\
\text { devisi yang } \\
\text { bertugas } \\
\text { mengirimka } \\
\mathrm{n} \text { invoice ke } \\
\text { klien }\end{array}$ \\
\hline 17 & $\begin{array}{l}\text { Kwitansi } \\
\text { yang tidak } \\
\text { sesuai } \\
\text { karna } \\
\text { ketukar } \\
\text { dengan } \\
\text { klien lain }\end{array}$ & $\begin{array}{l}\text { Merugikan } \\
\text { perusahaan } \\
\text { dan klien }\end{array}$ & \begin{tabular}{l}
\multicolumn{2}{l}{ Membuatka } \\
$\mathrm{n}$ from dan \\
dokumen \\
untuk setiap \\
klien \\
sehingga \\
tidak \\
tertumpuk \\
dalam \\
dokumen
\end{tabular} \\
\hline 18 & $\begin{array}{l}\text { Harga } \\
\text { training } \\
\text { yang tinggi } \\
\text { sehingga } \\
\text { klien } \\
\text { keberatan }\end{array}$ & $\begin{array}{l}\text { Tidak } \\
\text { adanya } \\
\text { kesepakatan } \\
\text { antar dua } \\
\text { pihak }\end{array}$ & $\begin{array}{l}\text { Memberikan } \\
\text { beberapa } \\
\text { pilihan } \\
\text { kepada klien } \\
\text { untuk harga } \\
\text { training } \\
\text { sesuai } \\
\text { dengan } \\
\text { tingkat } \\
\text { training } \\
\text { yang } \\
\text { diinginkan }\end{array}$ \\
\hline 19 & $\begin{array}{l}\text { Silabus } \\
\text { yang tidak } \\
\text { update }\end{array}$ & $\begin{array}{l}\text { Silabus akan } \\
\text { monoton } \\
\text { tidak ada } \\
\text { perubahan }\end{array}$ & \begin{tabular}{l}
\multicolumn{2}{l}{ Selalu } \\
mengevalua \\
si silabus \\
yang ada \\
sehingga ada \\
perbaharuan
\end{tabular} \\
\hline
\end{tabular}




\begin{tabular}{|c|c|c|c|}
\hline 20 & $\begin{array}{l}\text { Harga } \\
\text { instruktur } \\
\text { yang tinggi }\end{array}$ & $\begin{array}{l}\text { Merugiakan } \\
\text { perusahaan }\end{array}$ & $\begin{array}{l}\text { Menyediaka } \\
\mathrm{n} \quad \text { istruktur } \\
\text { cadangan } \\
\text { yang } \\
\text { dimiliki } \\
\text { perusahaan }\end{array}$ \\
\hline 21 & $\begin{array}{l}\text { Materi } \\
\text { training } \\
\text { yang tidak } \\
\text { update }\end{array}$ & $\begin{array}{l}\text { Tidak } \\
\text { adanya } \\
\text { inovasi yang } \\
\text { terbaharukan }\end{array}$ & $\begin{array}{l}\text { Mengevalua } \\
\text { si selalu } \\
\text { materi } \\
\text { materi setiap } \\
\text { kali training }\end{array}$ \\
\hline 22 & $\begin{array}{l}\text { Data } \\
\text { peserta } \\
\text { yang } \\
\text { berubah } \\
\text { ubah }\end{array}$ & $\begin{array}{l}\text { Memperlam } \\
\text { bat } \\
\text { pekerjaan }\end{array}$ & \begin{tabular}{l}
\multicolumn{2}{l}{ Memberikan } \\
from data \\
peserta \\
diawal pada \\
saat \\
konfirmasi \\
klien dan \\
tidak dapat \\
berubah \\
ubah
\end{tabular} \\
\hline 23 & $\begin{array}{l}\text { Kehabisan } \\
\text { stok } \\
\text { training kits } \\
\text { dan sovenir }\end{array}$ & $\begin{array}{l}\text { Harus } \\
\text { memesan ke } \\
\text { supplier lain }\end{array}$ & $\begin{array}{l}\text { Mempersiap } \\
\text { kan } \\
\text { beberapa } \\
\text { supplier } \\
\text { dalam untuk } \\
\text { penyedia } \\
\text { sovenir } \\
\end{array}$ \\
\hline 24 & $\begin{array}{l}\text { Nama yang } \\
\text { tidak sesuai } \\
\text { sehingga } \\
\text { salah } \\
\text { pengetikan }\end{array}$ & $\begin{array}{l}\text { Mengurangi } \\
\text { tingkat } \\
\text { kepuasaan } \\
\text { klien dan } \\
\text { merugikan } \\
\text { perusahaan }\end{array}$ & \begin{tabular}{l}
\multicolumn{2}{l}{ Memberikan } \\
from data \\
peserta \\
diawal pada \\
saat \\
konfirmasi \\
klien dan \\
tidak dapat \\
berubah \\
ubah apabila \\
berubah \\
menjadi \\
tanggung \\
jawab klien
\end{tabular} \\
\hline 25 & $\begin{array}{l}\text { Harga } \\
\text { sertifikat } \\
\text { yang tidak } \\
\text { sesuai }\end{array}$ & $\begin{array}{l}\text { Menganggar } \\
\text { kan kembali }\end{array}$ & $\begin{array}{l}\text { Bekerja } \\
\text { sama dengan } \\
\text { beberapa } \\
\text { supplier } \\
\text { dengan } \\
\text { harga yang } \\
\text { sudah di } \\
\text { anggarkan }\end{array}$ \\
\hline 26 & $\begin{array}{l}\text { Jumah } \\
\text { peserta } \\
\text { yang } \\
\text { bertambah } \\
\text { sehingga } \\
\text { data belum } \\
\text { masuk } \\
\text { untuk } \\
\text { pembuatan } \\
\text { sertifikat }\end{array}$ & $\begin{array}{l}\text { Meperlamba } \\
\mathrm{t} \text { dalam } \\
\text { membuat } \\
\text { sertifikat }\end{array}$ & \begin{tabular}{l}
\multicolumn{2}{l}{ Memberikan } \\
from data \\
peserta \\
diawal pada \\
saat \\
konfirmasi \\
klien dan \\
tidak dapat \\
berubah dan \\
memberi
\end{tabular} \\
\hline
\end{tabular}

\begin{tabular}{|c|c|c|c|}
\hline & & & $\begin{array}{l}\text { nama } \\
\text { cadangan } \\
\text { apabila } \\
\text { peserta yang } \\
\text { tidak dapat } \\
\text { hadir } \\
\text { digantikan } \\
\text { dengan } \\
\text { nama } \\
\text { cadangan }\end{array}$ \\
\hline 27 & $\begin{array}{l}\text { Terlambatn } \\
\text { ya } \\
\text { pelaksanaan } \\
\text { training } \\
\text { yang tidak } \\
\text { sesuai } \\
\text { dengan } \\
\text { waktu yang } \\
\text { ditentukan } \\
\end{array}$ & $\begin{array}{l}\text { Menurunya } \\
\text { tingkat } \\
\text { kepuasan } \\
\text { klien }\end{array}$ & $\begin{array}{l}\text { Mengevalua } \\
\text { si kembali } \\
\text { tingkat } \\
\text { disiplinnya } \\
\text { pelayanan } \\
\text { training dan } \\
\text { klien }\end{array}$ \\
\hline 28 & $\begin{array}{lr}\text { Data } & \text { yang } \\
\text { masuk } & \\
\text { berbeda } & \\
\text { dari } & \text { nama } \\
\text { dan } & \text { gelar } \\
\text { saat } & \text { di } \\
\text { cetak } & \end{array}$ & $\begin{array}{l}\text { Merugikan } \\
\text { perusahaan }\end{array}$ & $\begin{array}{l}\text { Sebelum } \\
\text { mencetak } \\
\text { memeriksa } \\
\text { kembali } \\
\text { nama dan } \\
\text { gekar pada } \\
\text { setiap } \\
\text { peserta }\end{array}$ \\
\hline 29 & $\begin{array}{l}\text { From } \\
\text { evaluasi } \\
\text { yang } \\
\text { kurang }\end{array}$ & $\begin{array}{l}\text { Terlambat } \\
\text { dalam } \\
\text { mengevaluas } \\
\text { i data klien }\end{array}$ & $\begin{array}{l}\text { Mencetak } \\
\text { lebih banyak } \\
\text { from } \\
\text { evaluasi }\end{array}$ \\
\hline 30 & $\begin{array}{l}\text { Terlambatn } \\
\text { ya } \\
\text { pengiriman } \\
\text { penagihan } \\
\text { ke klien. }\end{array}$ & $\begin{array}{l}\text { Belum } \\
\text { mendapatka } \\
\text { n profit }\end{array}$ & $\begin{array}{l}\text { Segera } \\
\text { mengirimka } \\
\text { n tagihan }\end{array}$ \\
\hline 31 & $\begin{array}{l}\text { Ketidakpah } \\
\text { aman atas } \\
\text { organisasi } \\
\text { perusahaan } \\
\text { sehingga } \\
\text { terjadi } \\
\text { kekurangan } \\
\text { efektifitas }\end{array}$ & $\begin{array}{l}\text { Kinerja } \\
\text { menurun }\end{array}$ & $\begin{array}{l}\text { Memberikan } \\
\text { pemahaman } \\
\text { dan evaluasi } \\
\text { terhadap } \\
\text { karyawan }\end{array}$ \\
\hline 32 & $\begin{array}{l}\text { Adanya } \\
\text { tumpang } \\
\text { tindih tugas } \\
\text { dan } \\
\text { tanggung } \\
\text { jawab }\end{array}$ & $\begin{array}{l}\text { Pekerjaan } \\
\text { yang tidak } \\
\text { teratur }\end{array}$ & \begin{tabular}{lr}
\multicolumn{2}{l}{ Memperjela } \\
s & untuk \\
setiap & devisi \\
apa & yang \\
harus & di \\
kerjakan & \\
sebagai & \\
tanggung & \\
jawabnya & \\
masing & \\
masing & \\
\end{tabular} \\
\hline 33 & $\begin{array}{l}\text { Tidak } \\
\text { terjadinya } \\
\text { rapat } \\
\text { evaluasi rutin } \\
\text { karna suatu }\end{array}$ & $\begin{array}{l}\text { Data keluhan } \\
\text { tidak } \\
\text { terlambat } \\
\text { tersampaikan }\end{array}$ & $\begin{array}{l}\text { Mengevalua } \\
\text { si kembali } \\
\text { dan mencari } \\
\text { hari } \\
\text { pengganti }\end{array}$ \\
\hline
\end{tabular}




\begin{tabular}{|c|c|c|c|}
\hline & hal & & \\
\hline 34 & $\begin{array}{l}\text { Klien yang } \\
\text { tidak } \\
\text { mudah } \\
\text { dihubungi }\end{array}$ & $\begin{array}{l}\text { Memperlam } \\
\text { bat rencana / } \\
\text { agenda } \\
\text { training }\end{array}$ & \begin{tabular}{lr}
\multicolumn{2}{l}{ Memberikan } \\
nomor \\
kontak klien \\
lebih \\
satu
\end{tabular} \\
\hline 35 & $\begin{array}{l}\text { Kurang } \\
\text { kooperative } \\
\text { nya semua } \\
\text { bagian saat } \\
\text { proses } \\
\text { penerimaan } \\
\text { klien } \\
\text { hingga } \\
\text { pelaksanaan } \\
\text { training. }\end{array}$ & $\begin{array}{l}\text { Menurunya } \\
\text { tingkat } \\
\text { kepuasan } \\
\text { klien }\end{array}$ & $\begin{array}{l}\text { Mengevalua } \\
\text { si kinerja } \\
\text { pelayanan } \\
\text { dalam } \\
\text { pelaksanaan } \\
\text { training }\end{array}$ \\
\hline 36 & $\begin{array}{l}\text { Penanganan } \\
\text { keluhan } \\
\text { klien } \\
\text { lambat }\end{array}$ & $\begin{array}{l}\text { Menurunya } \\
\text { tingkat } \\
\text { kepuasan } \\
\text { klien }\end{array}$ & $\begin{array}{l}\text { Mengevalua } \\
\text { si rutin dan } \\
\text { tersruktur } \\
\text { untuk } \\
\text { memperbaik } \\
\text { i menjadi yang } \\
\text { keluhan } \\
\text { klien }\end{array}$ \\
\hline 37 & $\begin{array}{l}\text { Ruang kerja } \\
\text { yang tidak } \\
\text { nyaman } \\
\text { sehingga } \\
\text { tidak } \\
\text { adanya } \\
\text { impact dari } \\
\text { hasil } \\
\text { pekerjaan } \\
\text { yang } \\
\text { diperoleh }\end{array}$ & $\begin{array}{l}\text { Efektifitas } \\
\text { karyawan } \\
\text { menurun }\end{array}$ & $\begin{array}{l}\text { Memeberika } \\
\mathrm{n} \quad \text { ruangan } \\
\text { yang } \\
\text { nyaman } \\
\text { kepada } \\
\text { karyawan }\end{array}$ \\
\hline 38 & $\begin{array}{l}\text { Jumlah } \\
\text { medsos } \\
\text { yang } \\
\text { tersebar } \\
\text { tidak sesuai } \\
\text { target }\end{array}$ & $\begin{array}{l}\text { Kehilangan } \\
\text { klien }\end{array}$ & $\begin{array}{l}\text { Mengevalua } \\
\text { si kembali } \\
\text { medsos yang } \\
\text { di sebar }\end{array}$ \\
\hline 39 & $\begin{array}{ll}\text { Medsos } & \\
\text { yang di } \\
\text { sebar dan } \\
\text { dibuat } & \\
\text { kurang } & \\
\text { menarik } & \\
\text { klien } & \end{array}$ & $\begin{array}{l}\text { Kehilangan } \\
\text { klien }\end{array}$ & $\begin{array}{l}\text { Membuat } \\
\text { medsos yang } \\
\text { menarik } \\
\text { berdasarkan } \\
\text { data dari } \\
\text { costumer } \\
\text { apa yang di } \\
\text { inginkan } \\
\text { mereka }\end{array}$ \\
\hline 40 & $\begin{array}{l}\text { IT yang } \\
\text { digunakan } \\
\text { sering error }\end{array}$ & $\begin{array}{l}\text { Kehilangan } \\
\text { klien }\end{array}$ & \begin{tabular}{l}
\multicolumn{2}{l}{ Mengevalua } \\
si kembali \\
untuk IT \\
yang \\
digunakan
\end{tabular} \\
\hline
\end{tabular}

Setelah melakukan evaluasi/ mitigasi risiko diharapkan ada penurunan yang signifikan terhadap risiko risiko yang kemungkinan bias terjadi pada seluruh aktivitas perusahaan yang berdampak Perusahaan Jasa Konsultasi PT. ABC.

\subsection{Pembahasan}

\subsubsection{Strategy \& Governance}

Pengendalian risiko untuk meningkatkan strategi dan tata kelola, manajemen harus:

Mengevaluasi semua karyawan dalam memahami strategi yang diterapkan oleh perusahaan sehingga diketahui seberapa banyak pemahaman karyawan tentang strategi yang telah diterapkan.

Mengevaluasi secara teratur untuk strategi yang telah dilaksanakan serta melakukan evaluasi selalu didokumentasikan untuk mengontrol setiap karyawan mengenai pemahaman tentang strategi yang diterapkan oleh perusahaan.

\subsubsection{Business Process}

Pengendalian risiko terhadap proses bisnis di PT. ABC yaitu:

Data dan jenis pelatihan yang diminta oleh klien harus jelas. Klien berikut harus lebih komunikatif sehingga klien tertarik. Negosiasi harga dan lokasi harus jelas. Pelatihan harus tepat waktu dan dalam memberikan suvenir, kit, dan sertifikat harus sesuai dengan data yang diterima.

Dalam proses bisnis, kita harus memperhatikan dengan baik apa yang diinginkan klien, untuk meningkatkan kepuasan klien.

\subsubsection{Structure}

Perlakuan risiko untuk struktur dalam perusahaan PT. ABC yaitu: memperjelas tugas dan tanggung jawab untuk setiap divisi dan karyawan dan mengevaluasi secara teratur untuk setiap divisi dan semua karyawan dan manajemen.

\subsubsection{People}

Pengendalian risiko bagi karyawan di PT. ABC dalam meningkatkan layanan selama pelaksanaan pelatihan untuk 
klien dan bagaimana manajemen memberikan kenyamanan kepada karyawan di tempat kerja yaitu menyediakan dan merancang ruang kerja yang nyaman serta selalu mengevaluasi kinerja karyawan, mengevaluasi layanan, dan melakukan pelatihan bagi karyawan untuk meningkatkan kepuasan klien.

\subsubsection{Technology}

Pengendalian risiko dalam teknologi yang digunakan di perusahaan adalah:

Mengaktifkan divisi CRM untuk mengetahui jenis perilaku konsumen atau klien. Mengevaluasi media sosial yang digunakan seperti web atau media sosial lainnya dibuat semenarik mungkin untuk menarik klien. Lakukan perawatan rutin untuk TI yang digunakan oleh perusahaan.

\section{Kesimpulan}

Dari penelitian yang dilakukan dapat disimpulkan bahwa:

Pada seluruh aktivitas PT. ABC yang bergerak pada bidang jasa terdapat 40 jenis risiko yang terdiri dari dari 5 variabel yakni strategy \& governance, proses bisnis, struktur, karyawan dan teknologi. Dari 40 risiko terdapat 24 potensi risiko yang berwarna merah (risiko besar) dan 16 potensi risiko yang berwarna kuning (risiko sedang).

Dari 24 potensi yang berisiko besar terdiri dari masing masing variabel yang terdiri dari strategy dan governance 3 risiko, Proses bisnis 14, people 4 risiko dan teknologi 3 risiko. Proses bisnis menjadi penyumbang risiko terbanyak dalam aktivitas perusahaan sehingga harus menjadi perhatian yang besar dari perusahaan PT. ABC karena proses bisnis memiliki peran cukup vital dalam perusahaan dan pelayanan ke klien maupun mirta kerja.

Dari hasil analisis dan mitigasi risiko, perusahaan harus memperhatikan risiko yang terjadi, serta mengevaluasi semua aktivitas perusahaan mulai dari strategi perusahaan, proses bisnis, struktur organisasi, karyawan dan teknologi untuk meningkatkan kinerja, kualitas layanan dan kepuasan klien.
Saran untuk penelitian selanjutnya dapat menambahkan perhitungan kerugian dengan aspek keuangan dari proses bisnis.

\section{Daftar Pustaka}

Abisay, T.G., dan Nurhadi. (2013). Manajemen Risiko pada Bandara Soekarno Hatta Berbasis ISO 31000. Jurnal Teknik Industri. Vol.14,No.2., 116-129.

Candra, R. M., Sari, Y. N., Iskandar, I., dan Yanto, F. (2019). Sistem Manajamen Risiko Keamanan Aset Teknologi Informasi Menggunakan ISO 31000:2018. Jurnal CoreIT, Vol.5, No.1., 19-28.

Dewi, D. (2012). Penerapan Sistem Manajemen Risiko pada Industri Nasional sebagai Masukan untuk Program PLTN. Prosiding Seminar Nasional Pengembangan Energi Nuklir V. 2012, Jakarta, Indonesia. 68-76

De Oliveira, U. R., Marins, F. A. S., Rocha, H. M., dan Salomon, V. A. P. (2017). The ISO 31000 Standard In Supply Chain Risk Management. Journal Clean. Prod, Vol. 151., 616-633.

Dosen Pendidikan. (2019, 30 Maret). Pengertian Tecnologi. Circuit. 22 februari 2020. https://www.dosenpendidikan.co.id/digit al-marketing-adalah/.

Doherty \& Neil. (2000). Integrated Risk Management. New York: McGraw Hill.

Driantami H. T. I., Suprapto. Dan Perdanakusuma A. R. (2018). Analisis Risiko Teknologi Informasi Menggunakan ISO 31000 (Studi kasus: Sistem Penjualan PT Matahari Department Store Cabang Malang Town Square). Jurnal Pengembangan Teknologi Informasi dan Ilmu Komputer. Vol. 2, No. 11., 4991-4998.

Edvardsson, B., Gustafsson, A., dan Roos, I. (2005). Service Portraits In Service Research A Critical Review. International Journal of Service Industry Management, Vol. 16, No.1., 107-121.

Febriyanti, A., dan Hidayanto, B.C. (2012). Manajemen Risiko pada Pengelolaan 
Data di Bagian Pengolahan Data PT Petrokimia Gresik. Jurnal Teknik Pomits. Vol.1, No. 1., 1-6.

Haksever C., Render B., Russell R. S., \& Murdick R. G. (2000). Service Management and Operations(2 ed.). Singapore: Printce Hall.

IBFGInstitute. (2018, 12 april). Standar baru manajemen resiko ISO 31000:2018, Circuit. 22 februari 2020. https://ibfgi.com/risk-management$\underline{31000 /}$

ISO 31000. (2009). Risk Management Principles and Guidelines, in ISO 31000, 1 st ed., Switzerland.

Johnston, R. (2005). Service Operations Management: From The Roots Up. International Journal of Operations \& Production Management, Vol.25, No.12.,1298-1308.

Lam \& James. (2004). Enterprise Risk Management. Wiley.

Mahardika, K. B., Wijaya, A. F., dan Cahyono, A. D. (2019). Manajemen Risiko Teknologi Informasi Menggunakan ISO 31000: 2018 (Studi Kasus: CV. XY). Jurnal Sebatik. Vol. 23., 277-284.

Onoini. (2019, 10 April). Pengertian Structure Circuit. 22 februari 2020. https://www.onoini.com/pengertianstruktur-organisasi-menurut-para-ahli/.

Pelajaran. (2017, 2 Januari). Pengetian Strategy dan Governance. Circuit. 22 februari 2020. https://www.pelajaran.co.id/2017/02/pen gertian-strategi-menurut-pendapat-paraahli-terlengkap.html.

Remko, V .H. (2013). Supplier Relationship Management. Netherlands.

SBC Warburg. (2004). The Practice of Risk Management. Euromoney Book.

Sousa, V., De Almeida, N. M dan Dias, L. A. (2012). Risk Management Framework For The Construction Industry According to the ISO 31000:2009 Standard. Journal of Risk Analysis and Crisis Response, Vol 2, No. 4., 261-274.

Sutanto, S. (2012). Desain Enterprise Risk Management Berbasis Iso 31000 Bagi
Duta Minimarket Di Situbondo. Jurnal Ilmiah Mahasiswa Universitas Surabaya. Vol.1 No.1., 1-18.

The British Standards Institution.(2018). Risk Management ISO 31000 . Penerbit: BSI Standards Publication.

Trend Ilmu. (2016, Maret). Pengertian Proses Bisnis. Circuit. 22 februari 2020. https://www.idjurnal.com/2016/03/penge rtian-pemodelan-proses-bisnis.html.

Yoga Utama, Y. P., dan Punjawa, I. N. (2009). Manajemen Resiko di PT. Industri Kereta Api (Persero) Untuk Menghadapi Ketidakpastian Supply Chain. Prosiding Seminar Nasional Manajemen Teknologi IX. Surabaya 14 Februari. 